\title{
Tanggungjawab perusahaan dalam investasi surat berharga syariah negara
}

\section{Dewi Astutty Mochtar ${ }^{1}$, Dewi Ayu Rahayu ${ }^{2}$.}

${ }^{1}$ Dewi Astutty Mochtar; Fakultas Hukum Pascasarjan Universitas Merdeka Malang; Jl. Terusan Raya Dieng Nomor 62-64; Malang; 65146; Jawa Timur; Indonesia.

${ }^{2}$ Dewi Ayu Rahayu; Fakultas Hukum Universitas Merdeka Malang; Jl. Terusan Raya Dieng Nomor 62-64; Malang; 65146; Jawa Timur; Indonesia.

\begin{tabular}{l} 
A R T I C L E I N F O \\
\hline Article history: \\
Received 2021-04-09 \\
Received in revised form \\
2021-05-12 \\
Accepted 2021-08-01 \\
\hline
\end{tabular}

Kata kunci:

Tanggungjawab perusahaan;

Investasi; Surat berharga syariah.

Keywords:

Corporate Responsibility;

Investment; Sharia Securitues.

DOI: https://doi.org/10.26905/

idjch. v12i2.6224.

How to cite item:

Mochtar, DA \& Rahayu, DA (2021). Tanggungjawab perusahaan dalam investasi surat berharga syariah negara. Jurnal Cakrawala Hukum, 12(2), 150-158. doi:10.26905/idjch.v12i2.6224.

Corresponding Author:

* Dewi Astutty Mochtar.

E-mail address: dewi.astutty@gmail.com.

\section{Abstrak}

Tulisan ini di latar belakangi oleh adanya inovasi baru dalam dunia pasar modal maupun perbankan yakni suatu investasi sukuk (surat berharga syariah negara) yang merupakan investasi obligasi berdasarkan prinsip syariah yang dapat diterbitkan oleh perusahaan maupun pemerintah. Investasi sukuk di terbitkan untuk pembiayaan anggaran pendapatan dan belanja negara termasuk pembangunan suatu proyek. Investasi sukuk terdapat berbagai macam jenisnya karena akad yang digunakan ketika berinvestasi pun bermacam-macam. Setiap investasi pasti akan menimbulkan kerugian bagi para pihak, maka hal ini pun kerugian juga akan dialami oleh setiap investor yang melakukan suatu investasi, begitu juga dengan investasi sukuk, investor juga dapat mengalami resiko kerugian. Kerugian yang dapat dialami oleh setiap investor berbeda yang disebabkan karena akad dalam berinvestasi sukuk berbeda. Kerugian yang dialami oleh investor yang disebabkan oleh kelalaian dari pihak pengelola (perusahaan) maka perusahaan harus bertanggung jawab atas kerugian yang ditimbulkan karena kelalaiannya, sejauh mana tanggung jawab perusahaan tergantung seberapa besar kelalaian yang dilakukan perusahaan hingga menyebabkan kerugian terhadap investor.

Abstract
This paper is motivated by the existence of new innovations in the world of capital
markets and banking, namely an investment sukuk (state sharia securities) which is
a bond investment based on sharia principles that can be issued by companies or
governments. Sukuk investment is issued to finance the state budget, including the
construction of a project. There are various types of sukuk investments because the
contracts used when investing also vary. Every investment will certainly cause
losses for the parties, so this will also be a loss for every investor who makes an


investment, as well as sukuk investment, investors can also experience the risk of loss. Losses that can be experienced by each investor are different due to the different contracts in investing in sukuk. Loss experienced by investors is caused by negligence on the part of the management (company) then the company must be responsible for losses incurred due to negligence, the extent to which the company's responsibility depends on how much negligence the company did to cause losses to investors.

\section{Pendahuluan}

Dalam Islam berinvestasi merupakan kegiatan bermuamalah yakni suatu kegiatan dalam bidang ekonomi yang didasarkan pada aturanaturan yang terdapat dalam hukum Islam. Islam menganjurkan berinvestasi karena dengan berinvestasi harta yang dimiliki menjadi produktif dan juga mendatangkan manfaat bagi orang lain.

Perkembangan ekonomi syariah yang semakin pesat di Indonesia menuntut adanya instrumen-instrumen syariah yang mendukung perkembangan tersebut. Instrumen-instrumen itu dikembangkan oleh lembaga-lembaga keuangan syariah seperti bank-bank dan lembaga pasar modal berbasis syariah. Meningkatnya jumlah dan variasi instrumen syariah memberikan alternatif investasi yang lebih luas kepada investor sehingga mendorong pertumbuhan investasi syariah di Indonesia (Badan Pengawas Pasar Modal, 2007).

Dalam rangka menciptakan kemaslahatan bagi para pelaku bisnis, kegiatan usaha lembaga keuangan yang berlaku harus disesuaikan dengan prinsip-prinsip syariah. Usaha penyesuaian yang telah dilakukan selama ini di antaranya terkait dengan perubahan peraturan perundang-undangan dan/atau ketentuan-ketentuan lain yang berhubungan dengan akad-akad operasionalnya (Burhanuddin, 2010).

Perkembangan yang pesat di dunia bisnis dan keuangan telah mendorong berkembangnya inovasi transaksi-transaksi keuangan syariah. Masyarakat tidak perlu lagi khawatir untuk berinvestasi karena lembaga keungan syariah juga banyak memiliki produk berinvestasi salah satunya adalah Sukuk Negara (Surat Berharga Syariah Negara) atau obligasi syariah yang tidak menggunakan bunga tetapi dengan bagi hasil (profit and loss sharing) berdasarkan prinsip syariah (dalam penulisan selanjutnya disebut dengan Sukuk).

Pesatnya perkembangan industri keuangan syariah juga diikuti oleh pesatnya perkembangan instrumen keuangan dan pembiayaan syariah yaitu sukuk yang lebih dahulu dikenal dengan istilah obligasi syariah. Dari segi struktur dan akad yang digunakan, instrumen keuangan syariah yang ada saai ini relatif terbatas. Namun sejalan dengan semakin besarnya permintaan dan kebutuhan investor, semakin banyak pula variasi struktur dan akad yang dikenalkan oleh pelaku pasar.

Berbagai bentuk investasi secara Islami telah dikembangkan sekarang ini, baik yang dipraktikkan oleh perbankan dan institusi Islam lainnya di berbagai negara yang penduduknya mayoritas Muslim. Di antara bentuk investasi dimaksud adalah Islamic dept securities, Islamic unit trust, Islamic asset-backed securities dan Islamic venture capital, termasuk instrumen sukuk yang merupakan produk baru dalam sistem pembiayaan Islam (Nazaruddin, 2010).

Namun, sejatinya sukuk bukanlah tema baru dalam sejarah Islam. Pada abad pertengahan, istilah ini sudah digunakan oleh para peniaga Muslim yang melakukan transaksi perdagangan dan aktivitas komersial lain yang bersifat multinasional, sebagai bukti (klaim) kepemilikan aset investasi. Sukuk tidak saja memerhatikan sisi keuntungan saja, tapi juga halal-haramnya barang, bentuk produksinya, dan besaran sistem bagi hasil sesuai aset yang disukukkan. 
Pada praktiknya sukuk secara umum diidentikkan sebagai "obligasi" yang penerapannya sesuai dengan prinsip - prinsip syariah. Di Indonesia sendiri sukuk telah diatur dalam Undang Undang Nomor 19 Tahun 2008 Tentang Surat Berharga Syariah Negara, selain itu landasan hukum sukuk adalah Fatwa No. 69/DSN-MUI/III/2008 Tentang Surat Berharga Syariah Negara.

Sukuk dalam pasar modal islam (islamic capital market) sama dengan obligasi yang terdapat di pasar modal konvensional. Perbedaanya adalah obligasi merupakan surat hutang, sedangkan sukuk merupakan sertifikat bukti atas bagian penyertaan terhadap aset. Investasi sukuk, selain merupakan instrumen investasi yang halal dan sesuai syariah oleh Majelis Ulama Indonesia (MUI) juga merupakan investasi yang aman karena dijamin oleh negara. Pada bulan Maret 2018, pemerintah Indonesia menerbitkan Sukuk Ritel 010 (SR-010). Tujuan utama diterbitkannya SR-010 adalah untuk membiayai percepatan pembangunan infrastruktur di Indonesia. Target awal penjualan SR-010 oleh seluruh agen penjual yaitu sebesar Rp 8,1 triliun yang nantinya akan digunakan untuk membiayai pembangunan jalan, jembatan, bendungan, irigasi, asrama haji, KUA, sarana pendidikan tinggi, dan lain-lain (Nita Andriyani Budiman, 2018).

Bahwa sukuk atau obligasi syariah merupakan surat pengakuan kerjasama yang memiliki ruang lingkup yang lebih beragam dibandingkan hanya sekedar surat pengakuan utang. Keberagaman tersebut dipengaruhi oleh berbagai akad yang telah digunakan. Seperti akad mudharabah, murabahah, salam, istishna, dan ijarah (fatwa No: 32/DSN-MUI/IX/2002). Penerbitan sukuk berfungsi sebagai instrumen pembiayaan (financing) dan sekaligus investasi (investment) yang dapat ditawarkan ke dalam berbagai bentuk atau struktur sesuai akad syariah" (Burhanuddin, 2010).

Penerbitan sukuk, sesuai dengan international best practice, dapat dilakukan dengan cara bookbuilding, lelang dan private placement. Pener- bitan sukuk pada umumnya dilakukan melalui (Special Purpose Vehicle) SPV sebagai penerbit, namun dapat dilakukan secara langsung oleh obligor. Sukuk yang akan dikeluarkan pemerintah disebut dengan Surat Berharga Syariah Negara (SBSN) atau dapat juga Sukuk Negara. Sukuk ini merupakan surat berharga (obligasi) yang diterbitkan oleh pemerintah Republik Indonesia berdasarkan prinsip syari'ah. Perusahaan yang akan menerbitkan SBSN ini adalah merupakan perusahaan yang secara khusus dibentuk guna kepentingan penerbitan SBSN ini (special purpose vehicle-SPV) (Veithzal Rifai, 2012).

Sukuk diterbitkan dengan tujuan membiayai anggaran negara, diversifikasi sumber pembiayaan, memperluas basis investor, mengelola portofolio pembiayaan negara, dan menajmin tertib administrasi pengelolaan Barang Milik Negara. Selain itu, PP nomor XI.A.13 juga menyatakan bahwa sukuk merupakan efek syariah berupa sertifikat atau bukti kepemilikan yang bernilai sama dan mewakili bagian penyertaan yang tidak terpisahkan atau terbagi atas: 1) kepemilikan asset berwujud tertentu; 2) nilai manfaat dan jasa atas asset proyek tertentu atau aktivasi investasi tertentu, atau 3) kepemilikan atas asset proyek tertentu atau aktivitas investasi tertentu (Zaini Ibrahim, 2013).

Secara formal, sukuk mempresentasikan kepemilikan atas sebuah aset yan proporsional dalam jangka waktu tertentu ketika resiko dan pengembalian yang berhubungan dengan aliran kas yang dihasilkan oleh underlying aset (aset yang akan menjadi objek perjanjian) dalam sebuah kumpulan modal diserahkan kepada pemegang sukuk (investor) (Zamir Iqbal, 2008).

\section{Metode}

Jenis penelitian yang digunakan adalah Penelitian Hukum Empiris, yang berdasarkan ketentuan perundang-undangan yang berlaku dikaitkan dengan teori hukum serta melihat realita yang 
terjadi di masyarakat yaitu berkaitan dengan akad yang digunakan dalam investasi sukuk serta tanggung jawab perusahaan apabila investor mengalami kerugian. Adapun pendekatan masalah yang digunakan oleh peneliti adalah Yuridis Sosiologis, dengan mencari fakta dengan interpretasi yang tepat. Dimana penelitian ini mempelajari masalah-masalah dalam masyarakat, serta tata cara yang berlaku dalam masyarakat serta situasisituasi tertentu, termasuk tentang hubunganhubungan, kegiatan-kegiatan, sikap-sikap, pandangan-pandangan, serta proses-proses yang sedang berlansung dan pengaruh-pengaruh dari suatu fenomena.

\section{Pembahasan}

\subsection{Akad yang digunakan perusahaan dengan investor dalam investasi surat berharga syariah negara}

Akad merupakan suatu pernyataan kehendak dalam melakukan perikatan (akad) yang dapat menimbulkan akibat hukum yang dilakukan oleh pihak pertama (ijab) sedangkan pihak lain (qabul) menerima atau menyetujui kehendak pihak pertama.

Berdasarkan wawancara yang dilakukan kepada dalam berinvestasi sukuk akad yang digunakan bermacam-macam, tergantung kesepakatan antara para pihak yang menghendaki akad mana yang akan digunakan.

Di bawah ini akan dijelaskan tentang bentukbentuk akad yang dapat digunakan dalam berinvestasi sukuk:

a. Akad Ijarah, akad ijarah merupakan akad penyaluran dana untuk pemindahan hak guna manfaat atas suatu barang dalam waktu tertentu dengan pembayaran sewa (ujrah), antara perusahaan pembiayaan sebagai pemberi sewa (mu'ajjir) dengan penyewa (musta'jir) tanpa diikuti pengalihan kepemilikkan barang itu. Berdasarkan Pasal 1548 KUH
Perdata sewa menyewa dapat diartikan sebagai berikut: sewa menyewa sebagai persetujuan, dengan mana pihak yang satu mengikatkan dirinya untuk memberikan kenikmatan suatu barang kepada pihak lain selama waktu tertentu, dengan pembayaran suatu harga yang disanggupi oleh pihak yang terakhir itu.

Berdasarkan beberapa pengertian di atas, akad ijarah merupakan bentuk pertukaran atas objek tertentu yang menghasilkan manfaat beserta imbalan. Akad ijarah apabila objek yang diperjanjikan berupa benda disebut sewa menyewa, sedangkan apabila yang diperjanjikan berupa manfaatnya maka hal ini dapat disebut dengan upah mengupah.

Objek ijarah adalah berupa barang modal yang memenuhui ketentuan, antara lain: 1) Objek ijarah dalam penguasaan perusahaan sebagai pemberi sewa (muajjir); 2) Manfaat objek ijarah harus dapat dinilai; 3) Manfaat objek ijarah harus dapat diserahkan penyewa (musta'jir); 4) Pemanfaatan objek ijarah harus bersifat tidak dilarang secara syari'ah; 5) Manfaat objek ijarah harus dapat ditentukan dengan jelas; 6) Spesifikasi objek ijarah harus dinyatakan dengan jelas, antara lain melalui identifikasi fisik, kelayakan dan jangka waktu pemanfaatannya.

Dalam investasi sukuk menggunakan akad ijarah dikarenakan SPV dapat mensekuritiekan asset dan dijual kepada investor. Penjualan sukuk menyebabkan SPV mendapatkan dana yang dapat dibayarkan kepada pemilik aset (originator). Ketika aset disewa kembali oleh originator, maka SPV berkewajiban mengumpulkan sewa dari originator untuk diserahkan kepada investor.

SPV yang telah menjadi pemilik terhadap aset, boleh untuk tidak menjual kembali aset dimaksut kepada originator, sementara originator bermaksut untuk membeli semula underlying assets. Atau SPV akan menjual semula 
aset tersebut dengan harga baru sesuai dengan harga pasaran, sementara originator menginginkan untuk membelinya kembali dengan harga asal, oleh karena itu, akad yang lebih sesuai kontrak dimaksud adalah menggunakan akad bay' al-wafa', sebagaimana dalam bentuk bagan dibawah ini (Nazaruddin, 2010):

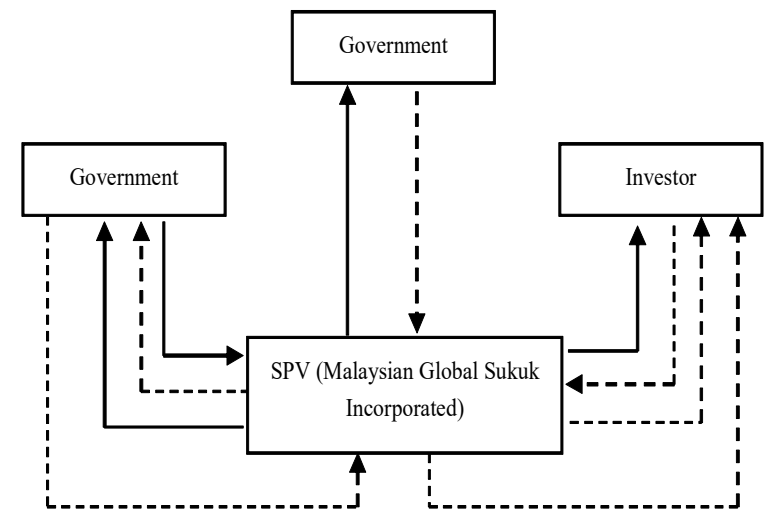

b. Akad istishna, akad istishna meruapakan akad yang digunakan dalam jual beli yang berbentuk pemesanan pembuatan barang tertentu dengan kriteria dan persyaratan tertentu. Istishna merupakan suatu perjanjian (akad) jangka menengah, dimana pihak penerima (penjual) menerima kehendak pihak pembeli untuk menyediakan barang tertentu yang sesuai dengan kehendak pembeli sesuai harga dan jangka waktu tertentu. Dalam investasi sukuk dengan menggunakan akad istishna terlebih dahulu untuk menetukan aset yang akan dijadikan jaminan, dan setelah aset selesai ditentukan dijual kepada pembeli.

c. Akad kafalah, akad kafalah merupakan akad dimana Pihak penjamin (kafiil/guarantor) berjanji memberikan jaminan kepada Pihak yang dijamin (makfuulanhu/ashil/debitur) untuk memenuhi kewajiban Pihak yang dijamin kepada pihak lain (makfuul lahu/kreditur). Oleh karena itu, kafalah merupakan akad yang digunakan untuk mengalihkan hak jaminan dari seseorang kepada pihak lain.
Ketentuan Umum dalam menggunakan akad kafalah, adalah sebagai berikut: 1) Pernyataan ijab dan qabul harus dinyatakan oleh para pihak untuk menunjukkan kehendak mereka dalam mengadakan kontrak (akad); 2) Dalam akad kafalah, penjamin dapat menerima imbalan (fee) sepanjang tidak memberatkan; 3) Kafalah dengan imbalan bersifat mengikat dan tidak boleh dibatalkan secara sepihak.

Dalam kafalah yang dapat dijaminkan adalah berupa jaminan kebendaan dan/atau jaminan umum seperti jaminan perusahaan dan jaminan pribadi. Objek Kafalah adalah kewajiban (utang) pihak yang dijamin kepada pihak yang dijaminkan (makfuul lahu/orang yang berpiutang) yang memenuhi ketentuan sebagai berikut: 1) Kewajiban dimaksud dapat berupa kewajiban pembayaran sejumlah uang, penyerahan barang, dan/atau pelaksanaan pekerjaan; 2) Kewajiban dimaksud harus jelas nilai, jumlah, dan spesifikasinya; 3) Kewajiban dimaksud bukan merupakan kewajiban yang timbul dari hal-hal yang bertentangan dengan Prinsip-prinsip Syariah di Pasar Modal dan peraturan perundangan-undangan; 4) Harus merupakan utang mengikat yang tidak mungkin hapus kecuali setelah dibayar atau dibebaskan.

d. Akad Mudharabah, akad mudharabah merupakan perjanjian (akad) kerja sama antara pemilik modal (Shahibul maal) dengan pelaku usaha (Mudharib) dengan cara shahibul maal menyerahkan sejumlah modal kepada mudharib untuk mengelola modal tersebut dalam suatu usaha.

Mudhorobah adalah suatu bentuk kontrak yang lahir sejak zaman RasulullahSAW, sejak zaman jahiliyah/sebelum Islam. Dan Islam menerimanya dalam bentuk bagi hasil dan investasi. Dalam Bahasa Arab ada tiga istilah yang digunakan untuk bentuk organisasi bisnis ini: Qiradh, Muqoqodah dan Mudhorobah (Nurul Iflaha, 2019). 
Dalam sukuk penerbit sertifikat disebut dengan mudharib, sedangkan pihak penyumbang modal atau pemilik modal disebut shahibul maal, dan dana yang dikumpulkan merupakan modal mudharabah.

Di bawah ini merupakan gambaran tentang sukuk mudharabah menurut Nazaruddin Abdul Wahid:

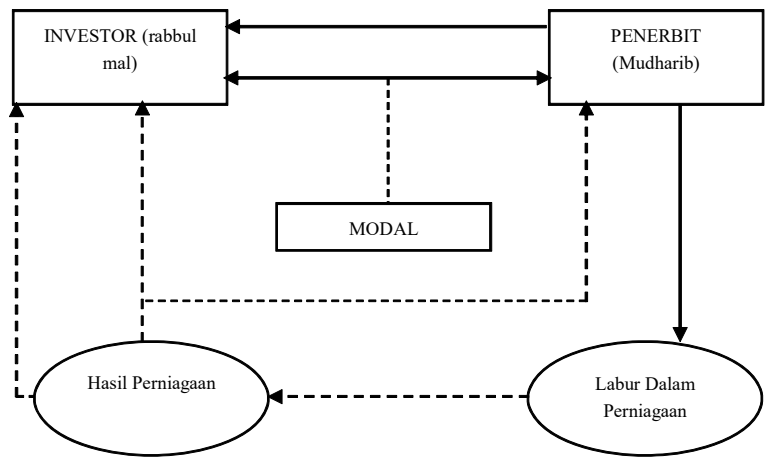

Berdasarkan gambar di atas dapat dijelaskan bahwa penerbit memproses penerbitan sukuk mudharabah untuk keperluan memobilisasi modal dengan kadar tertentu, penerbit dan investor membuat kontrak mudhrabah dengan perjanjian keuntungan yang telah diepakati, atas perjanjian tersebut, modal mudharabah terkumpul sejumlah tertentu, penerbit menanamkan modal pada proyek perniagaan sebagai peluang baik dalam alternatif perniagaan.

e. Akad musyarakah, akad musyarakah merupakan perjanjian (akad) kerjasama antara dua pihak atau lebih dengan menyertakan modal guna membiayai suatu proyek baik dalam bentuk uang maupun aset dimana hasil yang diperoleh dari kegiatan tersebut akan dibagi berdasarkan nisbah yang telah disepakati di dalam perjanjian (akad) tersebut.

Dalam berinvestasi sukuk dengan menggunakan akad musyarakah terdapat beberapa unsur yang harus dipenuhi: 1) Terdapat 2 (dua) orang atau lebih; 2) Masing - masing pihak turut menyertakan modal, baik berupa uang maupun aset lain yang dapat dinilai dengan uang; 3)
Tanggung jawab para pihak untuk menjalankan usaha secara bersama-sama; 4) Tujuan untuk mendapatkan keuntungan bukan tolong menolong; 5) Keuntungan dibagikan rasio (nisbah) yang telah disepakati sebelumnya oleh para pihak;

f. Akad wakalah, akad wakalah merupakan perjanjian (akad) antara pihak pemberi kuasa dengan pihak penerima kuasa, dimana pihak pemberi kuasa memberikan kuasanya terhadap penerima kuasa untuk melakukan suatu perbuatan tertentu. Syarat untuk para pihak dalam akad wakalah pihak pemberi kuasa dan pihak penerima kuasa harus memiliki kecakapan dan kewenangan untuk melakukan perbuatan hukum menurut ketentuan peraturan perundang-undangan.

\subsection{Tanggung jawab perusahaan ketika inves- tor mengalami kerugian akibat kesalahan perusahaan}

Prinsip umum dalam berinvestasi adalah adanya risiko, tidak ada satupun bentuk investasi yang kebal dari risiko kerugian. Fluktuasi nilai dalam berinvestasi akan sangat bergantung pada underlying asset nya. Resiko yang biasa dihadapi oleh suatu perusahaan, berkaitan dengan kemungkinan pengurangan nilai pendapatan dan nilai aset bagi pihak-pihak yang berkontrak, yang dengannya dapat menyebabkan kerugian.

Produk sukuk sebagaimana produk investasi lainnya, tidak terlepas dari kemungkinan akan menghadapi berbagai resiko, apalagi karena sukuk selain sebagai salah satu produk baru dalam pasar modal, juga terikat dengan mekanisme kontrak yang sesuai syara', menyebabkan produk sukuk akan mengalami resiko tersendiri sesuai menurut jenis kontrak yang dipilih.

Dalam berinvestasi sukuk, seorang investor juga tidak terlepas dari sebuah resiko atau kerugian yang dapat dialami oleh investor. Kerugian yang 
timbul dalam investasi sukuk pun beragam yang dikarenakan beragam pula akad yang digunakan dalam investasi.

Kerugian yang dapat dialami oleh investor, ketika investor meggunakan akad ijarah dimana dalam kesepakatan pembuatan perjanjian (akad) telah dipenuhinya rukun dan syarat serta kadar sewa objek tertentu. Tetapi, ketika dalam pertengahan perjanjian (akad) kadar harga pasaran meningkat yang menyebabkan kadar sewa terhadap aset juga ikut meningkat, maka dengan demikian pihak penyewa akan mengalami kerugian, dan hal ini akan berlaku sebaliknya ketika harga pasar menurun.

Selain itu kerugian juga dapat dialami oleh investor, ketika investor menggunakan akad musyarakah atau mudharabah, dalam sebuah akad terdapat beberapa pihak yang terlibat dalam investasi sukuk, ketika salah satu pihak (mitra) tidak melaksanakan kewajibannya atau mudarrib lalai dalam mengelola modal maka hal ini akan berdampak kerugian terhadap investor (shahibul maal).

Dalam investasi sukuk terdapat tiga tahapan pembuatan perjanjian, yakni akad antara originator dengan SPV pada saat pembentukan underlying assets, akad antara SPV dengan investor pada saat pengeluaran dan penjualan sukuk dan pada saat penebusan setelah tiba masa jatuh tempo. Dengan keadaan demikian resiko yang bisa timbul pada saat pensekuritian dan transfer assets kepada SPV, jika transfer tersebut dilakukan bukan dalam bentuk jaminan aset saja, maka dapat menyebabkan SPV gagal menguasai aset yang mengakibatkan terjadinya resiko operasional sukuk dan resiko kredit yang dihadapi SPV dan investor, dengan hal ini investor dapat mengalami kerugian.

Selain kerugian yang disebabkan karena penggunanaan akad dalam berkontrak sukuk, resiko pun dapat terjadi pada investasi sukuk ritel, yakni antara lain: a. Resiko gagal bayar (default risk) adalah resiko dimana investor tidak dapat memperoleh pembayaran dana yang dijanjikan oleh penerbit pada saat produk investasi jatuh tempo; b. Resiko pasar (market risk) adalah potensi kerugian bagi investor (capital loss) karena menjual sukuk ritel sebelum jatuh tempo (pada saatnya nilai turun). Resiko pasar dapat terjadi bagi sukuk, berhubungan dengan harga pasar disebabkan oleh: 1) Perubahan nilai faedah pasaran global yang dikaitkan dengan pengelolaan kredit. Produk sukuk pada umumnya menggunakan nilai bayaran keuntungan ditentukan secara tetap, seperti dalam kontrak ijarah, salam, murabahah, dan istisna. Namun, apabila harga pasaran meningkat menyebabkan investor mendapat kerugian; 2) Mengenai nilai tukar tetap dan berubah berkaitan dengan masalah pembiayaan; 3) Berhubungan dengan likuiditas, dimana sukuk dapat dengan mudah mendapat likuiditas dalam pasar modal; c. Resiko likuiditas (liquidity risk) adalah kesulitan dalam pencarian, resiko ini bisa disebabkan karena kecenderungan produk syariah di-hold (tidak diperjualbelikan hingga jatuh tempo), tetapi untuk sukuk ritel para agen penjual telah menjamin untuk membeli barang yang dijual investor. Resiko yang bisa terjadi adalah investor terpaksa menjual kepada agen penjual dengan harga di bawah pasar.

Dalam setiap produk investasi tidak ada yang bebas dari suatu resiko kerugian, investasi sukuk pun dapat menimbulkan kerugian bagi investor, kerugian yang dapat dialami oleh investor akibat kesalahan perusahaan, maka perusahaan harus bertanggung jawab atas kesalahannya.

Berdasarkan pasal 1366 KUHPerdata disebutkan bahwa "Setiap orang bertanggungjawab tdak saja untuk kerugian yang disebabkan perbuatannya, tetapi juga untuk kerugian yang disebabkan kelalaian atau kurang hati-hatinya".

Berdasarkan pasal 1366 KUHPerdata di atas maka setiap orang yang karena kelalaianya menyebabkan orang lain mengalami kerugian harus bertanggungjawab, oleh karena itu ketika investor mengalami kerugian yang diakibatkan kelalaian 
dari perusahaan, maka dengan hal ini perusahaan harus bertanggung jawab.

Kerugian yang ditimbulkan dalam sukuk dengan akad ijarah, dimana kerugian disebabkan pada faktor eksternal yakni berubahnya kadar faedah yang menyebabkan investor mengalami kerugian, maka dalam hal ini perusahaan bertanggung jawab untuk mengurus kerugian yang dialami oleh investor.

Tanggung jawab yang dilakukan oleh perusahaan yakni dengan menggunakan kaidah floating rate return (kadar keuntungan terapung), pengurusan tanggung jawab seperti ini adalah dengan melakukan perubahan pada kontrak ijarah dengan merubah kadar sewa pada nilai faedah dan menginvestasikan kembali aset (underlying assets), dengan hal ini kerugian yang dialami oleh investor akan tercover.

Pada investasi sukuk dengan akad mudharabah, kerugian yang ditimbulkan akibat kelalaian perusahaan pengelola modal, maka tanggung jawab yang dilakukan perusahaan adalah dengan bertanggung jawab sesuai dengan modal yang disediakan dengan ketentuan bahwa perusahaan terbukti melakukan kesalahan dalam mengelola modal.

Seseorang yang menggunakan aset real, tentu akan bertanggung jawab terhadap kerugian dan keuntungan secara serentak. Sedangkan kontrak yang didasarkan pada kadar faedah, telah memisahkan hak atas keuntungan dengan tanggung jawab terhadap kerugian.

Pada resiko yang berdasarkan dengan perjanjian yang melibatkan sejumlah tahapan dalam pelaksanaanya, mulai dari persekuritian aset, pengeluaran sukuk, perniagaan sukuk, dan penebusannya. Pada masing-masing tahapan tersebut melibatkan aliran dana dan transfer kekayaan antara pihak-pihak yang terlibat. Maka, apabila dengan hal tersebut terdapat resiko kerugian, secara umum dapat diatasi dengan proses pensekuritian dan secara khusus dapat diurus sesuai bentuk perjanjian yang dihadapi.

Pensekuritian tersebut dapat mengurangi resiko yang terjadi akibat kegagalan transfer aset dari originator kepada SPV dan dari SPV kepada investor serta pada saat penebusan sukuk dari SPV kepada originator akan dapat diselesaikan.

Ketika kerugian yang terjadi pada investor dalam sukuk ritel dalam resiko pasar, maka perusahaan dapat menyelesaikan resiko tersebut dengan cara: 1) Menggunakan kaidah floating rate return (kadar keuntungan terapung); 2) Melakukan evaluasi dalam jangka masa tertentu dan memperbarui kontrak sesuai dengan ketentuan harga baru.

Bentuk penyelesaian yang dilakukan perusahaan pada resiko pasar, sama dengan penyelesaian pada kerugian pada akad ijarah. Tanggung jawab yang telah dilakukan perusahaan di atas berdasarkan bentuk kerugian yang dialami oleh investor, ketika kerugian yang dialami oleh setiap investor berbeda maka bentuk tanggung jawab yang dilakukan oleh perusahaan pun berbeda.

\section{Simpulan}

Akad merupakan suatu pernyataan kehendak dalam melakukan perikatan yang dapat menimbulkan akibat hukum yang dilakukan oleh pihak pertama (ijab) sedangkan pihak lain (qabul) menerima atau menyetujui kehendak pihak pertama. Akad yang digunakan dalam investasi sukuk berbagai macam jenisnya, yakni akad ijarah, akad istishna, akad kafalah, akad mudharabah, akad musyarakah, dan akad wakalah, oleh karena itu tergantung kesepakatan investor dengan perusahaan akad mana yang ingin digunakan, karena akad banyak jenisnya maka kerugian yang akan dialami oleh investor pun beragam, tergantung akad yang digunakan.Kerugian pada dasarnya jumlah pengeluaran atau biaya yang lebih besar dibandingkan dengan pendapatan yang diterima. 


\section{Jurnal Cakrawala Hukum, Volume 12 No. 2 Agustus 2021}

ISSN PRINT 2356-4962 ISSN ONLINE 2598-6538

Kerugian yang dialami oleh investor dalam berinvestasi sukuk bermacam-macam, investor yang satu dengan investor yang lain kerugian yang dialami pun berbeda, oleh karena itu bentuk tanggung jawab yang dilakukan oleh perusahaan pun berbeda. Misalnya, dalam berinvestasi sukuk menggunakan akad mudharabah dimana pihak pengelola modal (perusahaan) tidak melaksanakan kewajibannya yang menyebabkan investor mengalami kerugian, oleh karena itu perusahaan harus bertanggung jawab atas kerugian yang diterima investor akibat perusahaan yakni dengan bertanggung jawab sebesar modal yang dilalaikan. Ketenagakerjaan.

\section{Daftar pustaka}

Abd., S. 2011. Tajdid pada Akad Pembiayaan Murabahah di Bank Syariah. Masalah-Masalah Hukum, 40(1), 1-9. doi:10.14710/mmh.40.1.2011.1-9.

Budiman, N. A. 2019. Analisis minat masyarakat dalam berinvestasi sukuk. Al-Urban: Jurnal Ekonomi Syariah Dan Filantropi Islam, 2(2), 146-154. https:/ /doi.org/10.22236/alurban_vol2/is1pp92-106
Burhanudin, S. 2010. Aspek Hukum Lembaga Keuangan Syariah. Edisi Pertama. Yogyakarta: Graha Ilmu.

Ibrahim, Z. 2013. Potensi Sukuk Sebagai Alternatif Pembiayaan Pembangunan di Banten. Al Qalam, 30(2), 293-318. Retrieved from http:// jurnal.uinbanten.ac.id/index.php/alqalam/article/view/1068.

Iflaha, N. 2019. Konsep Akad Mudhorobah Musytarokah Dalam Ekonomi Islam. LAN TABUR: Jurnal Ekonomi Syariah, 1(1), 1-21. https://doi.org/ 10.1234/lan tabur. v1i1.3537.

Iqbal, Zamir \& Abbas Mirakhor. 2008. Pengantar Keuangan Islam. Edisi Pertama. Jakarta: Kencana.

Ridwan, M., \& Wahjoeno, D. (2019). Perspektif Akad Murabahah Dalam Bank Syari'ah. LAN TABUR: Jurnal Ekonomi Syariah, 1(1), 22-43. https:// doi.org/10.1234/lan tabur. v1i1.3538.

Rifai, Veithzal. 2012. Islamic Banking and Fnance. Edisi Pertama. Yogyakarta: BPFE.

Wahid, Nazaruddin Abdul. 2010. Sukuk: Memahami \& Membedah Obligasi Pada Perbankan Syariah. cetakan I. Yogyakarta: Penerbit Ar-ruzz Media. 